\title{
Early Suppression of Rack Storage Fires with K363 Standard Response Sprinkler
}

\author{
HSIANG-CHENG KUNG ${ }^{1}$, SUNGCHUL LEE ${ }^{1}$, ROBERT J. BALLARD ${ }^{1}$, and MARC W. \\ MOSELEY ${ }^{2}$ \\ ${ }^{1}$ Victaulic Company \\ 4901 Kesslersville Road \\ Easton, PA 18040 USA \\ ${ }^{2}$ FM Approvals LLC \\ 743A Reynolds Road \\ West Glocester, RI 02814 USA
}

\begin{abstract}
A series of five large-scale fire tests has been conducted to evaluate the fire suppression performance of a standard response large K-factor pendent sprinkler for protection of rack storages of Standard Plastic Commodity under a 9.1 or $12.2 \mathrm{~m}$ high ceiling. The sprinkler has a nominal $25.4 \mathrm{~mm}$ orifice diameter and a nominal $363 \mathrm{~L} / \mathrm{min} /(\text { bar })^{1 / 2}$ discharge coefficient ( $\mathrm{K}$-factor). The activation mechanism is a standard response solder link, rated at $72{ }^{\circ} \mathrm{C}$, with a response time index (RTI) of $130(\mathrm{~m} \cdot \mathrm{s})^{1 / 2}$. The sprinkler spacing was maintained at $3 \mathrm{~m} \times 3 \mathrm{~m}$ and the deflector to ceiling distance was $343 \mathrm{~mm}$. Test variables included sprinkler discharge pressure, storage height, ceiling clearance and ignition location.
\end{abstract}

Two fire scenarios were used to evaluate the fire suppression performance of the sprinkler: 1) a fire between two sprinklers with low ceiling clearance $(1.8 \mathrm{~m})$ to evaluate sprinkler spray overlapping ability; 2) a fire underneath a sprinkler with large ceiling clearance $(3.4 \mathrm{~m})$ to evaluate sprinkler spray penetration ability against the fire plume.

For the $12.2 \mathrm{~m}$ ceiling height, the sprinkler at a discharge pressure of $0.21 \mathrm{MPa}$ and a sprinkler discharge rate of $522 \mathrm{~L} / \mathrm{min}$ achieved fire suppression for both the two fire scenarios. For the $9.1 \mathrm{~m}$ ceiling height, the sprinkler at a discharge pressure of $0.07 \mathrm{MPa}$ with a discharge rate of $302 \mathrm{~L} / \mathrm{min}$ or at a discharge pressure of $0.10 \mathrm{MPa}$ with a discharge rate of $369 \mathrm{~L} / \mathrm{min}$ provided fire suppression performance for the first scenario. For the second fire scenario under a $9.1 \mathrm{~m}$ high ceiling, the sprinkler at a discharge pressure of $0.07 \mathrm{MPa}$ with a discharge rate of $302 \mathrm{~L} / \mathrm{min}$ only achieved fire control.

Actual delivered densities (ADD) of the sprinkler for some of the test conditions employed in the largescale fire tests were measured. The large water drops generated from the large K-factor (K363) sprinkler enhance its penetration ability against the fire plume. The ADD data confirms that as the ADD is greater than the required delivered density (RDD) for fire suppression, suppression of the fire can be expected. The results of the five fire tests show that a standard response K363 sprinkler can be as effective as ESFR sprinklers in providing protection for storage in warehouses with ceiling height up to $12.2 \mathrm{~m}$.

KEYWORDS: standard response, large K-factor, sprinklers, rack storage fire.

\section{INTRODUCTION}

For the past 50 years, since the introduction of the standard sprinkler, industrial occupancies have undergone dramatic changes in manufacturing and storage practices, such as the introduction of new synthetic materials and use of forklift trucks that allow high-rack storage arrangements. Fires in this rack storage environment are characterized by extremely fast fire growth, high heat release rate, and high plume velocity, and have challenged the standard sprinkler to its limit of effectiveness. In response to these challenges, a series of research programs to study the principles of sprinkler performance in rack storage fires has been conducted from 1970 to 1995 , in an effort to provide a sound technical basis for new sprinkler designs [1]. The scientific principles include sprinkler sensitivity (response time index [2]) measurement, prediction of sprinkler activation [3,4], spray penetration ability through fire (actual delivered density, ADD [5,6]), and fire suppression requirement of rack storage fires (required delivered density, RDD [7]). Aided by these scientific principles, the desired effectiveness of sprinkler fire protection 
can be ensured and the optimal use of water quantity can be determined, which results in cost-effective sprinkler protection of storages in warehouses.

These scientific principles were used in aiding the development of the early suppression fast response (ESFR) sprinklers [1]. Since the introduction of ESFR sprinklers in 1987, ESFR sprinklers have become the most popular sprinklers for warehouse protection. The ESFR sprinklers are designed to respond to a fire at its early stage of development and to discharge a large quantity of water over the fire to achieve fire suppression. Although many other ceiling sprinkler systems and in-rack sprinkler systems can also achieve fire suppression for certain storage occupancies; nowadays, we tend to associate sprinkler suppression performance of rack-storage fires with only fast response sprinklers. Although, a fast response sprinkler responds to a fire sooner than the standard response sprinkler and make it easier for water drops to penetrate the fire plume and reach the burning fuel, fast response alone is not the necessary and sufficient condition for a sprinkler system to achieve fire suppression. More importantly, it is the condition, ADD greater than RDD, being met; then, fire suppression can be expected. ADD is a measure of sprinkler spray penetration ability through the fire plume that depends on the water drop size, spray pattern, discharge rate, discharge pressure, and fire size.

Ceiling clearance and ignition location are also very important test variables for large-scale fire testing and ADD measurements. Two fire scenarios have regularly been used to evaluate performance of sprinklers in large-scale fire testing: 1$)$ a fire between two sprinklers with a low ceiling clearance (1.8 $\mathrm{m}$ clearance) to evaluate sprinkler spray overlapping ability; 2) a fire underneath a sprinkler with a large ceiling clearance (3.4 $\mathrm{m}$ clearance) to evaluate sprinkler spray penetration ability against the fire plume. These two fire scenarios were also employed in this study to evaluate a standard response large K-factor sprinkler for protection of rack storages of the Standard Plastic Commodity under a 9.1 or $12.2 \mathrm{~m}$ high ceiling.

Actual delivered densities (ADD) of the sprinkler for some of the large-scale sprinkler fire test parameters were also measured in this study. The large water drops generated from the large K-factor (K363) sprinkler enhance the sprinkler penetration ability against the fire plume. The ADD data confirm that as the ADD exceeds the required delivered density (RDD) for fire suppression, early suppression of the fire is expected. This study demonstrates that for a given fire scenario, the fire suppression performance of sprinklers depends on the combined effects of the sprinkler attributes: sprinkler orientation (pendent or upright), sprinkler $\mathrm{K}$ factor, sprinkler deflector design for generating the desirable spray pattern, volume median diameter of the spray, sprinkler sensitivity (RTI) and temperature rating.

\section{LARGE-SCALE FIRE TESTS}

\section{Test Plan}

A series of five large-scale fire tests has been conducted to evaluate the fire suppression performance of a standard-response K363 sprinkler for protection of rack storages of the Standard Plastic Commodity under a 9.1 or $12.2 \mathrm{~m}$ high ceiling. The sprinkler model is a pendent sprinkler with a nominal $25.4 \mathrm{~mm}$ orifice diameter and a discharge coefficient (K-factor) of $363 \mathrm{~L} / \mathrm{min} /\left(\right.$ bar $^{1 / 2}{ }^{1 /}$ The sprinkler temperature rating is $72{ }^{\circ} \mathrm{C}$, and the sprinkler has a response time index (RTI) of $130(\mathrm{~m} \cdot \mathrm{s})^{1 / 2}$. The sprinklers were installed in nominal $63.5 \mathrm{~mm}$ diameter piping at $3 \mathrm{~m} \times 3 \mathrm{~m}$ spacing; deflectors were located $343 \mathrm{~mm}$ below the ceiling. Test variables included sprinkler discharge pressure, storage height, ceiling clearance and ignition location.

For the two fire tests conducted with the $12.2 \mathrm{~m}$ ceiling height, the sprinkler discharge pressure was set at $0.21 \mathrm{MPa}$ and the sprinkler discharge rate was maintained at $522 \mathrm{~L} / \mathrm{min}$. The first test (Test 1) was conducted with $10.4 \mathrm{~m}$ high storages and $1.8 \mathrm{~m}$ ceiling clearance to investigate the low clearance effect on overlapping of sprinkler sprays, when the ignition was between two sprinklers. The second test (Test 2) was conducted with $8.8 \mathrm{~m}$ high storages and $3.4 \mathrm{~m}$ ceiling clearance with ignition under a sprinkler to evaluate the spray penetration ability against the fire plume.

For the $9.1 \mathrm{~m}$ ceiling height, three fire tests were conducted. Test 3 was conducted with $5.8 \mathrm{~m}$ high storages and $3.3 \mathrm{~m}$ ceiling clearance and with the fire underneath a sprinkler to investigate the spray penetration ability against the fire plume. In this test, the sprinkler discharge pressure was set at $0.07 \mathrm{MPa}$ with a discharge rate of $303 \mathrm{~L} / \mathrm{min}$. To evaluate the low clearance effect on overlapping effectiveness of sprinkler sprays, two fire tests (Tests 4 and 5) were conducted with $7.3 \mathrm{~m}$ high storages and $1.8 \mathrm{~m}$ ceiling clearance 
and with ignition centered below two sprinklers. Test 4 was conducted with a sprinkler discharge pressure of $0.07 \mathrm{MPa}$ and a discharge rate of $303 \mathrm{~L} / \mathrm{min}$; Test 5 was conducted with a discharge pressure of $0.1 \mathrm{MPa}$ and a discharge rate of $371 \mathrm{~L} / \mathrm{min}$. Table 1 summarizes the test parameters and test results of the five tests.

Table 1. Summary of test parameters and results.

\begin{tabular}{|c|c|c|c|c|c|}
\hline Fire test number & 1 & 2 & 3 & 4 & 5 \\
\hline \multicolumn{6}{|c|}{ Parameters } \\
\hline Storage height, $(\mathrm{m})$ & 10.4 & 8.8 & 5.8 & 7.3 & 7.3 \\
\hline $\begin{array}{c}\text { Main array size } \\
\text { in terms of pallet loads, } \\
(\mathrm{L} \times \mathrm{W} \times \mathrm{H})\end{array}$ & $8 \times 2 \times 7$ & $8 \times 2 \times 6$ & $8 \times 2 \times 4$ & $8 \times 2 \times 5$ & $8 \times 2 \times 5$ \\
\hline $\begin{array}{c}\text { Target array size } \\
\text { in terms of pallet loads, } \\
(\mathrm{L} \times \mathrm{W} \times \mathrm{H})\end{array}$ & $6 \times 1 \times 7$ & $6 \times 1 \times 6$ & $6 \times 1 \times 4$ & $6 \times 1 \times 5$ & $6 \times 1 \times 5$ \\
\hline Ceiling height, $(\mathrm{m})$ & 12.2 & 12.2 & 9.1 & 9.1 & 9.1 \\
\hline Clearance, $(\mathrm{m})$ & 1.8 & 3.4 & 3.4 & 1.8 & 1.8 \\
\hline Aisle width, (m) & 1.2 & 1.2 & 2.4 & 2.4 & 2.4 \\
\hline Ignition location & $\begin{array}{l}\text { Between } \\
\text { two } \\
\text { sprinklers }\end{array}$ & Under one & Under one & $\begin{array}{l}\text { Between } \\
\text { two } \\
\text { sprinklers }\end{array}$ & $\begin{array}{l}\text { Between } \\
\text { two } \\
\text { sprinklers }\end{array}$ \\
\hline Discharge pressure, $(\mathrm{MPa})$ & 0.21 & 0.21 & 0.07 & 0.07 & 0.1 \\
\hline $\begin{array}{c}\text { Sprinkler discharge rate, } \\
(\mathrm{L} / \mathrm{min})\end{array}$ & 522 & 522 & 302 & 302 & 369 \\
\hline \multicolumn{6}{|c|}{ Results } \\
\hline Length of test, (min:s) & 15 & 20 & 20 & 15 & 20 \\
\hline $\begin{array}{l}\text { First ceiling sprinkler } \\
\text { operation, (min:s) }\end{array}$ & $1: 42$ & $1: 32$ & $1: 24$ & $1: 35$ & $1: 25$ \\
\hline $\begin{array}{l}\text { Last ceiling sprinkler } \\
\text { operation, (min:s) }\end{array}$ & $1: 58$ & N/A & N/A & $1: 58$ & $1: 42$ \\
\hline $\begin{array}{c}\text { Number of operated } \\
\text { sprinklers }\end{array}$ & 3 & 1 & 1 & 8 & 5 \\
\hline $\begin{array}{l}\text { Time of ignition across } \\
\text { aisle, (min:s) }\end{array}$ & N/A & 2: 36 & No & No & No \\
\hline $\begin{array}{l}\text { Peak gas temperature at } \\
\text { ceiling above ignition, } \\
\left({ }^{\circ} \mathrm{C}\right)\end{array}$ & 486 & 109 & 124 & 527 & 308 \\
\hline $\begin{array}{l}\text { Maximum } 1 \text { min average } \\
\text { gas temperature at ceiling } \\
\text { above ignition, }\left({ }^{\circ} \mathrm{C}\right)\end{array}$ & 297 & 75 & 97 & 363 & 242 \\
\hline $\begin{array}{l}\text { Maximum steel } \\
\text { temperature, }\left({ }^{\circ} \mathrm{C}\right)\end{array}$ & 72 & 41 & 48 & 119 & 82 \\
\hline Fire spread across aisles & Limited & Limited & No & No & No \\
\hline
\end{tabular}

\section{Facility and Test Set-Up}

The fire tests were conducted in the Large Burn Room of the FM Global Research Campus, located at West Glocester, RI. Overall dimensions of the Large Burn Room are $73.2 \mathrm{~m} \times 42.7 \mathrm{~m} \times 20.4 \mathrm{~m}$ high, housing a $20 \mathrm{MW}$ fire products collector (a large-scale calorimeter) in the center of the room and two $24.4 \mathrm{~m} \times$ $24.4 \mathrm{~m}$ ceilings on either sides of the collector. The ceilings are movable and can be maintained at a specified height from the floor for a given test, with $9.14 \mathrm{~m}$ gaps between the edges of the ceiling and the building walls. All the five tests were conducted underneath the north movable ceiling. During the test, combustion gases were exhausted from four vents at the roof over the four corners of the ceiling, connected 
to an air pollution control system. The exhaust rate was set at $5663 \mathrm{~m}^{3} / \mathrm{min}$ of air at room temperature. Fresh air was supplied via banks of perforated plates on the west wall.

The Standard Plastic Commodity was used as fuel to provide a high challenge fire. The commodity [3] consists of rigid crystalline polystyrene jars packaged in single-wall, $0.53 \mathrm{~m}$ cube, corrugated paper cartons. The empty, $473 \mathrm{~mL}$ capacity, jars are compartmentalized within the carton with corrugated paper partitions. They are arranged in five layers, 25 per layer, for a total of 125 per carton. Eight cartons, arranged $2 \times 2 \times 2$, form a pallet load. Each pallet load is supported by a two-way, nominal $1.07 \mathrm{~m} \times$ $1.07 \mathrm{~m} \times 0.13 \mathrm{~m}$, slatted deck hardwood pallet.

In each test, a large-scale rack storage array was erected on the floor underneath the north movable ceiling. The array consisted of a double-row rack storage system (main rack system), where ignition would occur, and a single-row target rack system. Each row of the main rack system was comprised of four segments of open frame steel racking, $0.91 \mathrm{~m}$ wide $\times 2.44 \mathrm{~m}$ long bays, while the row of the target rack was comprised of three segments. The bays of the main rack system were loaded with pallet loads of the Standard Plastic Commodity to provide a nominal $0.15 \mathrm{~m}$ wide longitudinal and $0.15 \mathrm{~m}$ wide transverse flue spaces in the main rack storage. The target rack was also loaded with the Standard Plastic Commodity with $0.15 \mathrm{~m}$ wide transverse flues. The racks were divided vertically into $1.52 \mathrm{~m}$ high storage levels.

For Tests 1 and 2, the geometric center of the double-row main rack was positioned at the ceiling center. The target storage was positioned across a $1.22 \mathrm{~m}$ aisle space from the main rack, as measured from carton to carton. For Test 1, the main rack was centered below two sprinklers. Figure 1 shows the plan view of the storage array with respect to the ceiling. There were seven tiers in the main and the target rack systems. The storage height was $10.36 \mathrm{~m}$ and the clearance from the ceiling to the top of the storage was $1.83 \mathrm{~m}$.

For Test 2, the main rack was centered below a sprinkler. There were six tiers in the main and the target rack systems. The storage height was $8.84 \mathrm{~m}$ and the clearance from the ceiling to the top of the storage was $3.35 \mathrm{~m}$.

For Test 3, the geometric center of the double-row main rack was also positioned at the ceiling center; but the target storage was positioned across a $2.44 \mathrm{~m}$ aisle space from the main rack, as measured from carton to carton. The main rack was centered below a sprinkler. There were four tiers in the main and the target rack systems; the storage height was $5.79 \mathrm{~m}$ and the clearance from the ceiling to the top of the storage was $3.35 \mathrm{~m}$.

For Tests 4 and 5, there were five tiers in the main and the target rack systems. The storage height was $7.32 \mathrm{~m}$ and the clearance from the ceiling to the top of the storage was $1.83 \mathrm{~m}$. The geometric center of the double-row main rack was positioned $0.61 \mathrm{~m}$ west of the center axis of the ceiling, and the ignition was $0.61 \mathrm{~m}$ offset eastward from the center of the main rack system and was centered below two sprinklers. The target storage was positioned across a $2.44 \mathrm{~m}$ aisle space from the main rack, as measured from carton to carton.

Documentation for the tests included video recording and still photographs. Visual observations of test events and damage assessment were made. All data were recorded on a computerized data acquisition system. The following instrumentations were installed: 1) Sprinklers equipped with timing mechanisms installed in nominal $63.5 \mathrm{~mm}$ diameter piping at 56 locations for Tests, 1,4 and 5, and at 49 positions for Tests 2 and 3; 2) Bare-bead, 20-gage, chromel-alumel thermocouples, placed $0.15 \mathrm{~m}$ below the ceiling at 81 locations; 3) Nine thermocouples imbedded in a $1.22 \mathrm{~m}$ long steel angle $(50 \mathrm{~mm} \times 50 \mathrm{~mm} \times 6 \mathrm{~mm})$ attached to the ceiling over the main rack; 4) A heat flux gage mounted on the face of the target rack at one half the rack height and located opposite to the ignition flue, to measure radiant heat output of the fire; 5) Water flow meters and pressure gages to monitor the sprinkler system flow. The igniter was constructed from a $80 \mathrm{~mm}$ long by $80 \mathrm{~mm}$ diameter cotton roll, soaked with $113 \mathrm{~g}$ of gasoline and wrapped in a polyethylene bag. Two igniters were placed in the center transverse flue space in the double-row rack, at the base of the bottom-tier pallet loads, offset $0.61 \mathrm{~m}$. from the center of the rack to the face of the rack system. The igniters were lit with a flaming propane torch at the start of each test. 


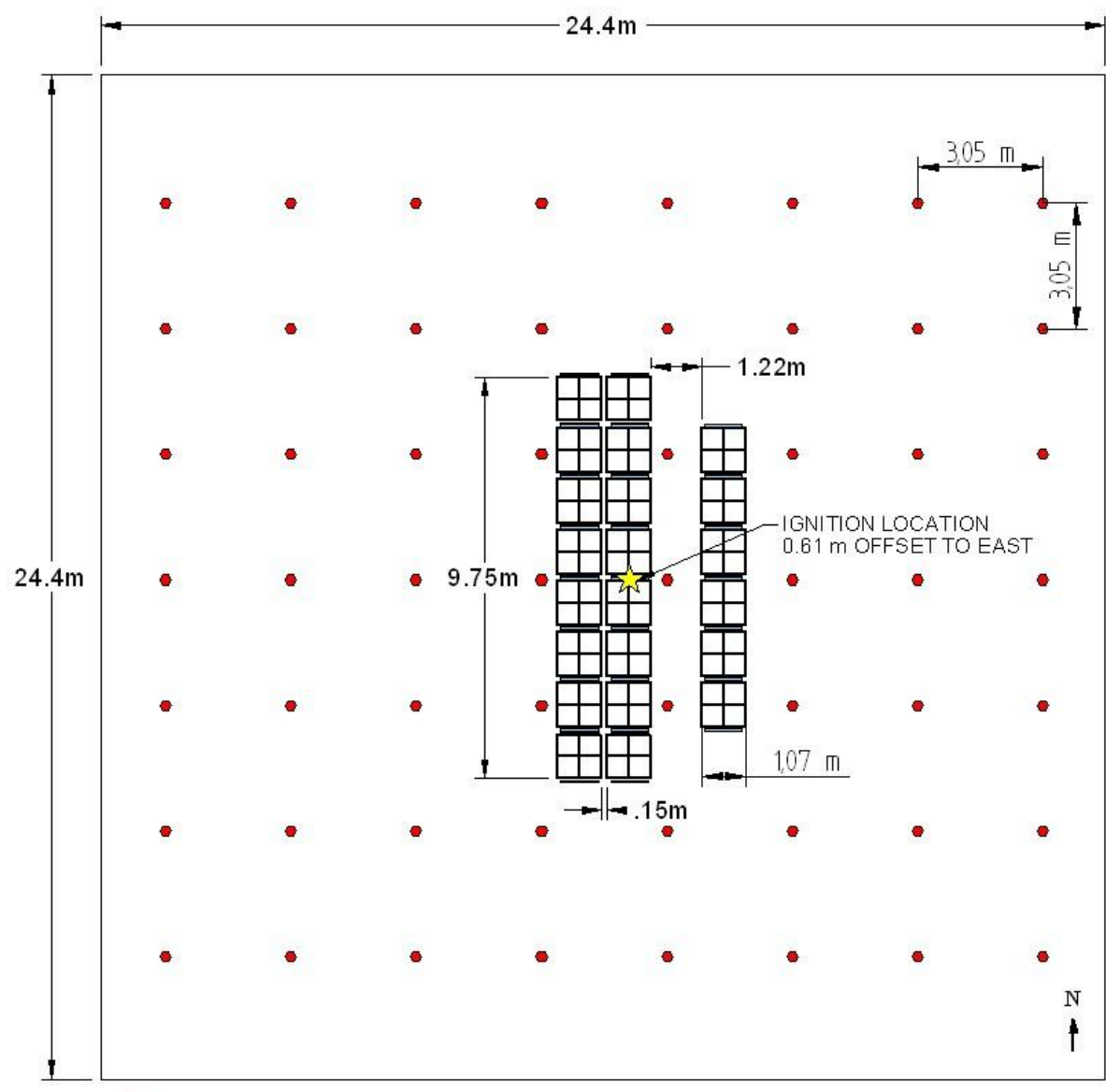

- SPRINKLER LOCATIONS

Fig. 1. Plan view of fuel array of Test 1.

\section{FIRE TEST RESULTS}

\section{Tests 1 and 2 - Ceiling Height: $12.2 \mathrm{~m}$}

In Test 1 , after ignition, the fire took approximately $40 \mathrm{~s}$ to reach the bottom of the third tier commodity and extend to the longitudinal flue. After the fire reached the third tier, it quickly spread to the top tier. At $60 \mathrm{~s}$ after ignition, flames reached the top of the seventh tier; at $92 \mathrm{~s}$, the flames impinged on the ceiling. The first sprinkler ( $1.5 \mathrm{~m}$ west of the geometric center of the double-row main rack system) activated at $102 \mathrm{~s}$ after ignition, $10 \mathrm{~s}$ after the flames impinged on the ceiling. Figure 2 shows the fire involvement at the time of sprinkler activation. The second sprinkler $(1.5 \mathrm{~m}$ east of the geometric center of the main rack system) and the third sprinkler ( $3 \mathrm{~m}$ south of the first sprinkler) operated 4 and $16 \mathrm{~s}$ later, respectively. The thermocouple located directly over the main rack center recorded its highest value of $486{ }^{\circ} \mathrm{C}$ at $100 \mathrm{~s}$ after ignition. Peak temperatures recorded at monitored locations within $4.57 \mathrm{~m}$ of the ceiling center were below $343{ }^{\circ} \mathrm{C}$. After sprinkler operations, these ceiling gas temperatures dropped steadily to $38^{\circ} \mathrm{C}$ within $5 \mathrm{~min}$. The fire was suppressed, as defined by the steady decrease of ceiling gas temperatures after sprinkler operations. The three operated sprinklers suppressed the fire effectively. The temperatures measured by the thermocouples embedded in the steel angle, which was installed on the ceiling over the ignition flue, remained below the level that would have resulted in damage to exposed structural steel. The peak recorded steel temperature was $72{ }^{\circ} \mathrm{C}$. The center two bays of the main rack system were involved in the fire. The west face of the target rack system did ignite however the damage was limited to one pallet load of commodity. 


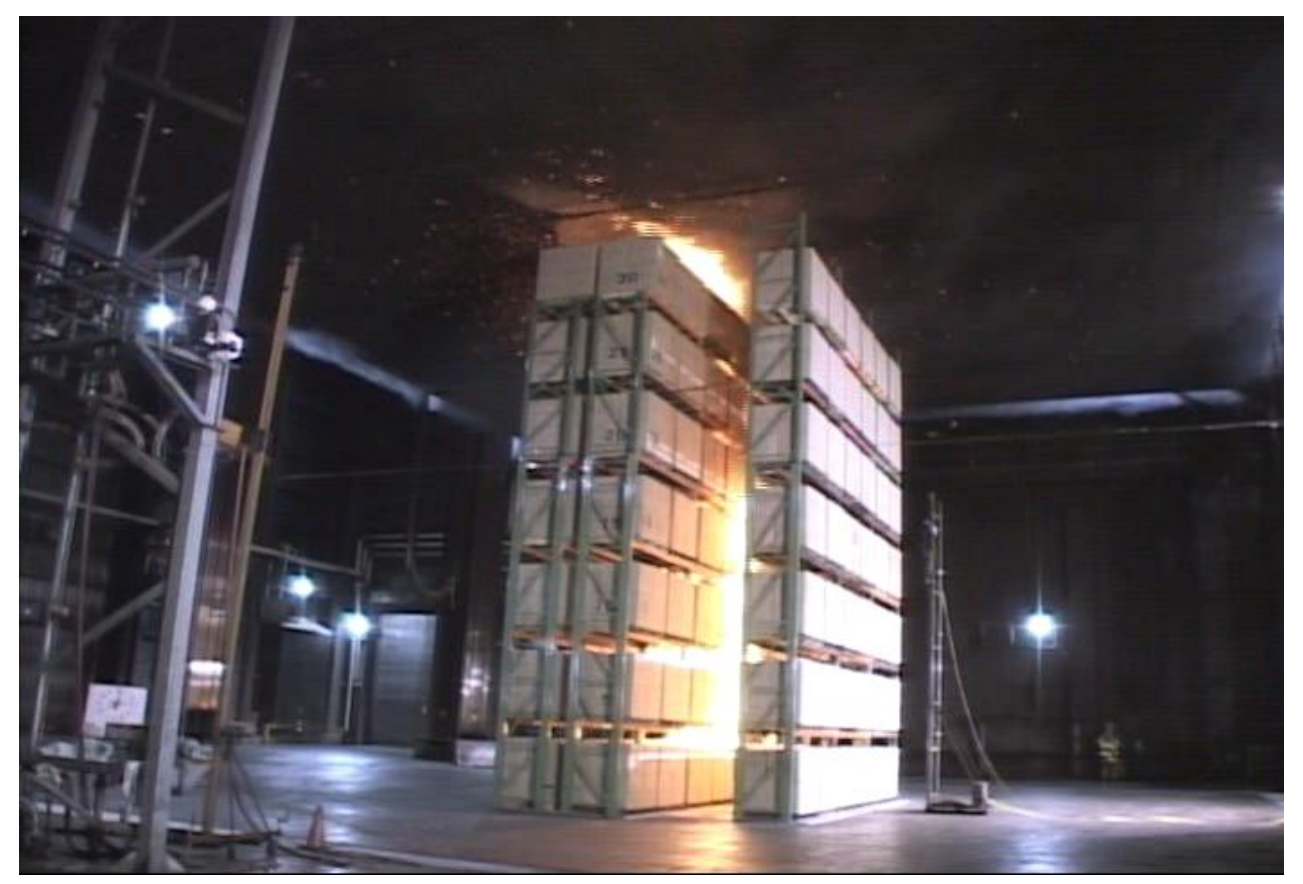

Fig. 2. Test 1 - Fire involvement at the time of sprinkler activation.

In Test 2, the fire reached the top of the sixth tier at $65 \mathrm{~s}$ after ignition. At $70 \mathrm{~s}$, flames extended out to the east face of the main rack storage. At $92 \mathrm{~s}$ after ignition, the sprinkler over the main rack center actuated and the single sprinkler operation was sufficient to suppress the fire. The thermocouple located directly over the main rack system center recorded its highest value of $109^{\circ} \mathrm{C}$ at $83 \mathrm{~s}$. Peak temperatures recorded at monitored locations within $4.57 \mathrm{~m}$ of the ceiling center were below $77^{\circ} \mathrm{C}$. After the sprinkler operation, these ceiling gas temperatures dropped steadily to $38^{\circ} \mathrm{C}$ within $4 \mathrm{~min}$. The peak steel-angle temperature was $41{ }^{\circ} \mathrm{C}$. The center two bays of the main rack system were involved in the fire; the west face of target rack system did ignite, however damage was limited to one pallet load of commodity.

\section{Tests 3, 4, and 5 - Ceiling Height: $9.1 \mathrm{~m}$}

In Test 3, the fire took about $20 \mathrm{~s}$ to reach the longitudinal flue. The fire reached the top of the second tier of commodity at $40 \mathrm{~s}$ after ignition. Afterwards, it quickly spread to the top of the fourth tier of commodity. At $65 \mathrm{~s}$, flames impinged on the ceiling. The sprinkler over the center of the main rack actuated at $84 \mathrm{~s}$ after ignition. The flames were driven back from the ceiling after the sprinkler activation but began to grow and re-establish themselves in the flue spaces, $60 \mathrm{~s}$ later. The thermocouple located directly over the main rack system center recorded its highest value of $124{ }^{\circ} \mathrm{C}$ at $85 \mathrm{~s}$. Peak temperatures recorded at monitored locations within $4.57 \mathrm{~m}$ of the point over the main rack system center remained below $93{ }^{\circ} \mathrm{C}$. After sprinkler operation, these temperatures were kept around $60^{\circ} \mathrm{C}$ for $10 \mathrm{~min}$ and then started to decrease afterward, as shown in Fig. 3. Since the ceiling gas temperatures did not decrease steadily after the sprinkler operation, as shown in Fig. 3, the fire was not considered being suppressed. Only one sprinkler operated in the fire test and controlled the fire. The peak steel-angle temperature was $48{ }^{\circ} \mathrm{C}$. The center two bays of the main rack system were involved in the fire, but the target rack system did not ignite. 

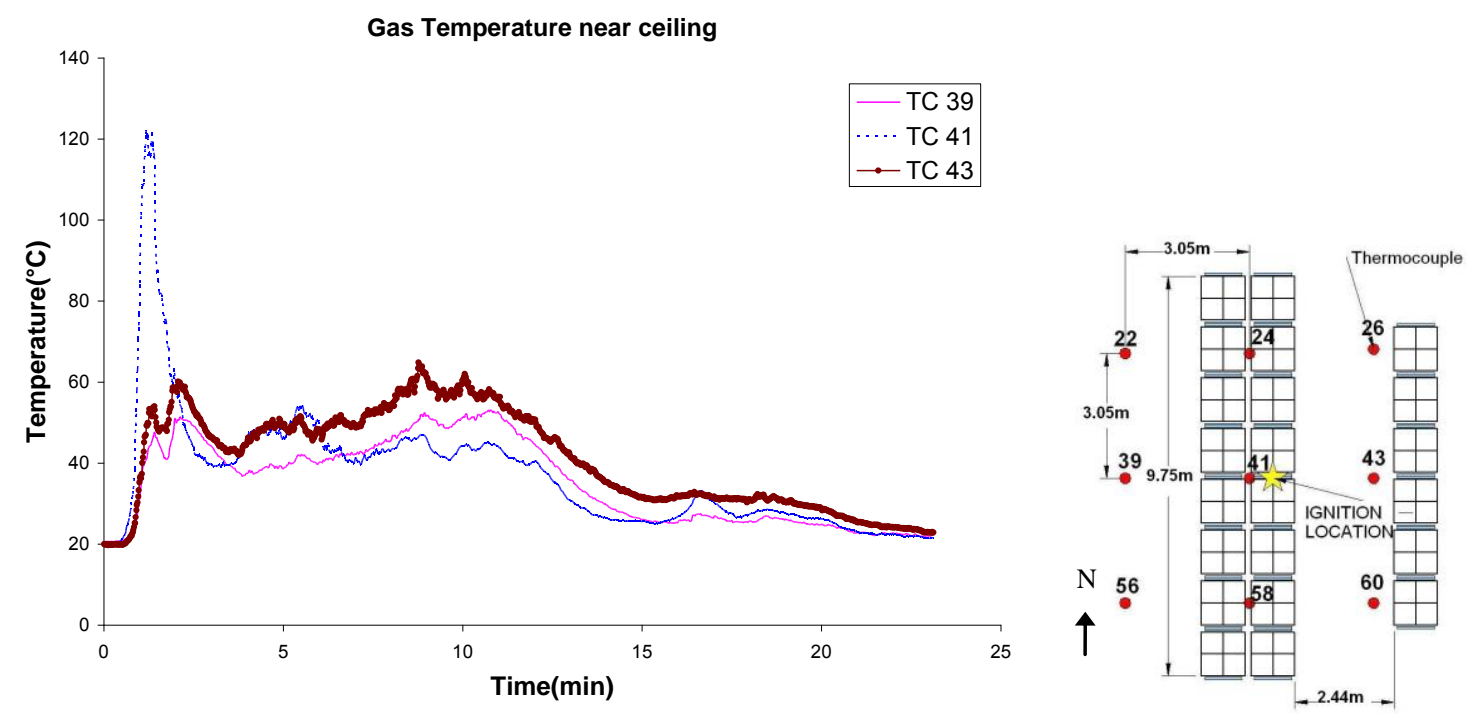

Fig. 3. Ceiling gas temperatures over the main rack in Test 3.

In Test 4 , the flames reached the top of the fifth tier commodity at $60 \mathrm{~s}$ after ignition. Ten seconds later, flames started to impinge on the ceiling and spread outward along the ceiling. At $95 \mathrm{~s}$ after ignition, the sprinkler $1.5 \mathrm{~m}$ west of the ignition point activated first. At $101 \mathrm{~s}$, the sprinkler $3 \mathrm{~m}$ south of the first operating sprinkler activated. At $106 \mathrm{~s}$, two sprinklers $3 \mathrm{~m}$ west of the two operating sprinklers activated, but were too far from the fire and had no effect on the fire. Within the next twelve seconds, four additional sprinklers activated. The sequence of sprinkler activations is shown in Fig. 4. As the sprinkler $1.5 \mathrm{~m}$ east of the ignition point activated at $116 \mathrm{~s}, 21 \mathrm{~s}$ after the first sprinkler activation ( $1.5 \mathrm{~m}$ west of ignition point) the fire intensity started to subside and the fire was suppressed. The center two bays of the main rack system were involved in the fire and the target rack system did not ignite. The thermocouple located directly over the ignition location recorded the highest value of $532{ }^{\circ} \mathrm{C}$ at $104 \mathrm{~s}$. Peak temperatures recorded at monitored locations within $4.57 \mathrm{~m}$ of the point over the ignition location remained below $458{ }^{\circ} \mathrm{C}$. After the sprinkler operations, these ceiling gas temperatures decreased to $38^{\circ} \mathrm{C}$ within $10 \mathrm{~min}$. The peak steel-angle temperature was $119^{\circ} \mathrm{C}$.

In Test 5, the flames started to impinge on the ceiling at $50 \mathrm{~s}$ after ignition. At $85 \mathrm{~s}$, the sprinkler $1.5 \mathrm{~m}$ west of the ignition point activated first. The sprinkler $4.24 \mathrm{~m}$ southwest of the first operating sprinkler and the sprinkler $3 \mathrm{~m}$ west of the first sprinkler activated at $97 \mathrm{~s}$ and $101 \mathrm{~s}$ after ignition, respectively; these two sprinklers were too far from the fire and had no effect on the fire. At $102 \mathrm{~s}$ the sprinkler $1.5 \mathrm{~m}$ east of the ignition point and the sprinkler $3.4 \mathrm{~m}$ southeast of ignition activated and the fire was suppressed. The thermocouple located directly over ignition recorded the highest value of $303{ }^{\circ} \mathrm{C}$ at $103 \mathrm{~s}$. Peak temperatures recorded at monitored locations within $4.57 \mathrm{~m}$ of the point over ignition was below $178{ }^{\circ} \mathrm{C}$. The center two bays of the main rack system were involved in the fire. The target rack system did not ignite. The peak steel-angle temperature was $82{ }^{\circ} \mathrm{C}$. As the sprinkler discharge rate increased from $303 \mathrm{~L} / \mathrm{min}$ in Test 4 to $371 \mathrm{~L} / \mathrm{min}$ in Test 5 , these ceiling gas temperatures in Test 5 decreased to $38{ }^{\circ} \mathrm{C}$ within 2 min after sprinkler operations, as compared to Test 4 , where the temperatures decreased to $38{ }^{\circ} \mathrm{C}$ within $10 \mathrm{~min}$. 


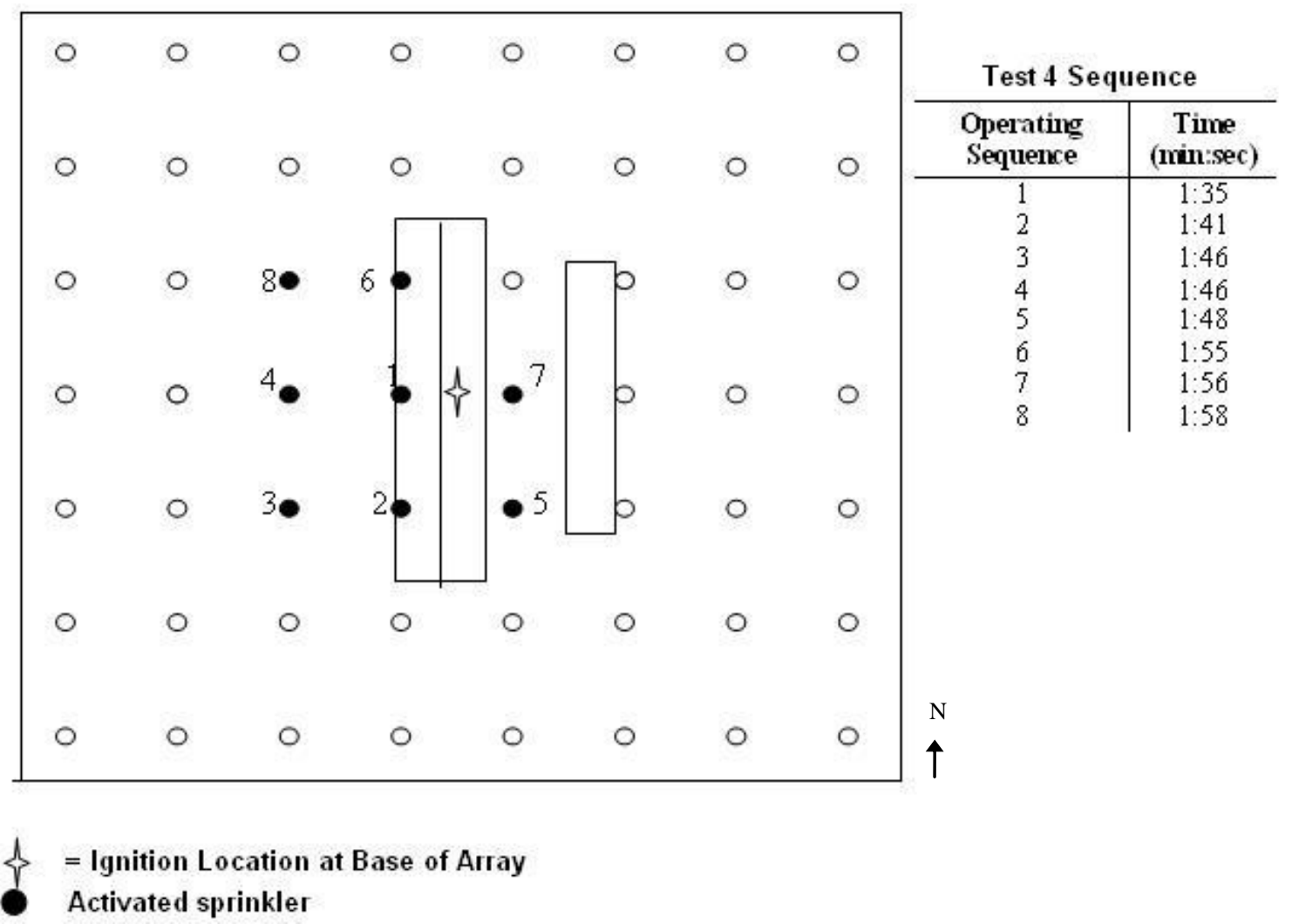

Fig. 4. Sequence of sprinkler activations for Test 4.

\section{ACTUAL DELIVERED DENSITY AND REQUIRED DELIVERED DENSITY}

Actual delivered densities (ADD) of the sprinkler for some of the test conditions employed in the largescale fire tests were measured with an ADD apparatus consisting of a fire plume simulator and a water collection assembly. The fire plume simulator consists of nine fuel spray nozzles using heptane as fuel. Eight identical nozzles are equally spaced on a $1.22 \mathrm{~m}$ diameter circle and are directed toward the centerline of the apparatus at an angle with respect to the horizontal plane. A nozzle was located at the center of the circle on a $102 \mathrm{~mm}$ diameter air deflecting plate. A $203 \mathrm{~mm}$ diameter duct is placed directly underneath the plate, supplying standard air at $18.4 \mathrm{~m}^{3} / \mathrm{min}$. A detailed description of the plume simulator can be found in Ref. [5].

Different fire sizes are obtained by changing spray nozzle size, nozzle angle with respect to the horizontal plane and fuel supply pressure. We estimate that the convective heat release rates of the rack storage fires at first sprinkler activation in this study to be around $2 \mathrm{MW}$, based on activation times of the K363 standard response sprinkler in the fire tests $[3,4,8,9]$. The nozzle selection and arrangement to achieve the $2 \mathrm{MW}$ convective heat release rate is presented in Table 1 of Ref. [5].

The water collection assembly consists of a total of 42 pans to simulate the top surface of a double-row rack storage segment, four pallet loads wide by two pallet loads deep, including the flue spaces between commodities. The top surface of each pallet load of commodity is represented by four square pans and the flue space between two adjacent pallet loads of commodity is fitted with a rectangular pan. There are 32 square pans and 10 rectangular pans. The water collected in each pan is channeled to an individual container and the weight of water in each container is monitored continuously. The heptane spray nozzles of the plume simulator are positioned $15.2 \mathrm{~cm}$ above the water collection pans, with the center nozzle at the center of the water collection assembly.

In the large-scale fire tests, ignition was in the center transverse flue space of the double-row rack system, offset $0.61 \mathrm{~m}$ from the center to the face of the rack system. As the fire grew, the fire plume quickly moved 
toward the longitudinal flue spaces of the rack storage system. At sprinkler activation, the fire plume exited from the center transverse flue and the longitudinal flue of the main rack system, similar to the fire plume generated by the plume simulator.

The measurements were conducted in the ADD Burn Room of the FM Global Research Campus under a $11.7 \mathrm{~m} \times 10.4 \mathrm{~m}$ suspended ceiling. The ceiling could be raised or lowered to a specified height from the floor. Overall dimensions of the ADD Burn Room are $15.2 \mathrm{~m} \times 23.1 \mathrm{~m} \times 9.14 \mathrm{~m}$ high. During a test, combustion gases were exhausted from four corner vents at the roof, connected to an air pollution control system. The exhaust rate was set at $850 \mathrm{~m}^{3} / \mathrm{min}$ of air at room temperature. Fresh air was supplied via banks of perforated plates on the east wall. For measurements of ADD with the main rack system centered below a sprinkler, an open sprinkler was installed in a nominal $63.5 \mathrm{~mm}$ diameter pipe with a sprinkler deflector to ceiling distance of $305 \mathrm{~mm}$. The sprinkler was centered over the water collection assembly with a ceiling to collection pan distance of $3.05 \mathrm{~m}$. For ADD with the main rack system centered between two sprinklers, two open sprinklers were installed in a sprinkler pipe at a spacing of $3.05 \mathrm{~m}$, and the collection assembly was centered between the two sprinklers with a ceiling to collection pan distance of $1.52 \mathrm{~m}$. The experimental procedure is described in the FM Global Operation Manual of ADD Apparatus.

The ADD is defined as the average water density (flux) over the center 20 water-collection pans consisting of 16 square pans and 4 rectangular pans; the area covered by these pans corresponds to the top surface of the center two pallet loads by two pallet loads segment of the main rack system, where ignition took place. The average water density over the rest of the pans on the left and the right sides of the center 20 pans is called the pre-wetting density (PWD). When the fire is not suppressed, fire spread beyond the center rack segment could be prevented with a sufficient PWD. ADD and PWD for the conditions employed in Tests 1, 2 and 3 have been measured and are presented in Table 2. The ADD without fire, i.e. $\mathrm{ADD}_{0}$, for Tests 1,2 and 3 were also measured. The penetration ratio of $\mathrm{ADD} / \mathrm{ADD}_{\mathrm{o}}\left(P_{e}\right)$ is a measure of penetration ability of the sprinkler sprays against the fire plume. $P_{e}$ for Tests 1,2 and 3 are $0.91,0.92$ and 0.70 , respectively. These high penetration ratios result from the large drop sizes generated from the large K-factor sprinkler. Since the center of the main rack system in Tests 4 and 5 was not centered between two sprinklers, but offset $0.61 \mathrm{~m}$ toward one of the two sprinklers, measurements of ADD and PWD for Tests 4 and 5 were not performed.

A large number of RDD tests were conducted to determine the RDD for the Standard Plastic Commodity in rack storage configurations [7]. The RDD was determined by uniformly applying water to the top of a two pallet load wide by two pallet load deep rack storage segment. The applied water density (flux) was varied to bracket the RDD for a selected rack storage height at a given fire size of water activation. The results also show that the RDD is not sensitive to the fire size at the time of water application for the fire sizes ranged from 1 to $2 \mathrm{MW}$. RDD for 4.57, 6.1, and $7.62 \mathrm{~m}$ high rack storage segments of the Standard Plastic Commodity have been determined as $16.3,20.4$ and $26.5 \mathrm{~mm} / \mathrm{min}$, respectively [1]. In a RDD test, the fire was started at the bottom of the center flue spaces of the rack storage segment. As water was applied to the top of the storage, it first covered the top surfaces and then cascaded downward along the vertical surfaces of the commodities. With higher storage, less water reached the fire at the bottom. We do not expect that RDD is linearly proportional to the storage height. Therefore, the three limited data points were correlated to establish an exponential relationship of RDD with respect to storage height, $H$, as the following: RDD = $7.69 \mathrm{e}^{0.162 H}$. Using this formula, the RDD values for 9.14 and $10.7 \mathrm{~m}$ high storage segments of the Standard Plastic Commodity are estimated to be 33.5 and $43.5 \mathrm{~mm} / \mathrm{min}$, respectively.

Comparing the ADD values measured for Tests 1, 2, and 3 with their respective RDD values shown in Table 2, the ADD for Test 1 is about the same as the RDD for $10.7 \mathrm{~m}$ high rack storage of Standard Plastic Commodity and the ADD for Test 2 is greater than the RDD for $9.14 \mathrm{~m}$ high rack storage; the fire in Tests 1 and 2 were suppressed, as indicated by the continuous decline of ceiling gas temperatures after sprinkler operation. In Test 3, the ADD is about $20 \%$ less than the RDD, the ceiling gas temperatures did not decrease continually after sprinkler operation, but were maintained around $60{ }^{\circ} \mathrm{C}$ for about $10 \mathrm{~min}$, as shown in Fig. 3. The fire in Test 3 was considered controlled but not suppressed.

The RDD is determined by applying water uniformly on the top surface of the rack storage segment, whereas, the ADD from sprinkler spray on the water collection surface is highly non-uniform. A strict 
ADD > RDD condition may not guarantee the suppression performance of a sprinkler. However, as the $\mathrm{ADD}$ is greater than or close to the RDD, it is likely that sprinkler fire suppression can be achieved.

Table 2. Actual delivery density, pre-wetting density, and required delivery density for Tests 1,2 , and 3 .

\begin{tabular}{|c|c|c|c|c|c|c|}
\hline Test number & \multicolumn{2}{|c|}{1} & \multicolumn{2}{|c|}{2} & \multicolumn{2}{|c|}{3} \\
\hline Fire source location & \multicolumn{2}{|c|}{$\begin{array}{l}\text { Between two } \\
\text { sprinklers }\end{array}$} & \multicolumn{2}{|c|}{$\begin{array}{l}\text { Under one } \\
\text { sprinkler }\end{array}$} & \multicolumn{2}{|c|}{$\begin{array}{l}\text { Under one } \\
\text { sprinkler }\end{array}$} \\
\hline Normal storage height, (m) & \multicolumn{2}{|c|}{10.7} & \multicolumn{2}{|c|}{9.1} & \multicolumn{2}{|c|}{6.1} \\
\hline $\begin{array}{l}\text { Collection pan to ceiling } \\
\text { clearance, }(\mathrm{m})\end{array}$ & \multicolumn{2}{|c|}{1.5} & \multicolumn{2}{|c|}{3.05} & \multicolumn{2}{|c|}{3.05} \\
\hline $\begin{array}{c}\text { Convective heat release rate, } \\
\text { (MW) }\end{array}$ & 2 & 0 & 2 & 0 & 2 & 0 \\
\hline $\mathrm{ADD},(\mathrm{mm} / \mathrm{min})$ & 41.2 & 45.2 & 38.3 & 41.6 & 16.3 & 23.2 \\
\hline $\mathrm{PWD},(\mathrm{mm} / \mathrm{min})$ & 16.3 & 13.0 & 14.7 & 19.1 & 5.7 & 9.0 \\
\hline $\mathrm{RDD},(\mathrm{mm} / \mathrm{min})$ & 43.5 & $\mathrm{n} / \mathrm{a}$ & 33.5 & $\mathrm{n} / \mathrm{a}$ & 20.4 & $\mathrm{n} / \mathrm{a}$ \\
\hline$P_{e}$ & \multicolumn{2}{|c|}{0.91} & \multicolumn{2}{|c|}{0.92} & \multicolumn{2}{|c|}{0.7} \\
\hline
\end{tabular}

\section{DISCUSSION AND CONCLUSION}

In this study, a standard response K363 sprinkler was evaluated in two fire scenarios. The two scenarios have also been used for evaluation of ESFR sprinkler fire performance. The evaluation criteria for ESFR sprinklers are: 1) only one sprinkler activates for the case with the ignition underneath a sprinkler, 2) no more than six sprinklers activate for the case with the ignition between two sprinklers, and 3) fire spread does not reach the outer boundary of the fuel array [9-12]. The test results show that the K363 sprinkler met all the criteria in the tests with $12.2 \mathrm{~m}$ ceiling height employing a discharge pressure of $0.21 \mathrm{MPa}$, and in the tests with $9.1 \mathrm{~m}$ ceiling height employing $0.10 \mathrm{MPa}$ discharge pressure.

Fire tests were conducted for a K202 ESFR sprinkler under a $12.2 \mathrm{~m}$ ceiling [9-11]. The sprinkler discharge rate in these tests was set at $459 \mathrm{~L} / \mathrm{min}$, and the discharge pressure was $0.51 \mathrm{MPa}$. Similar test results were obtained for the K202 ESFR sprinkler [9-11] as for the K363 sprinkler. The ceiling gas temperatures in these tests also decreased steadily after sprinkler actuations. To achieve similar fire performance, the discharge rate of the K363 sprinkler was $14 \%$ more than that of K202 ESFR sprinkler, but the discharge pressure was considerably lower, $0.21 \mathrm{MPa}$ for the K363 sprinkler as compared to 0.51 MPa for the K202 ESFR sprinkler. The low end-head discharge pressure requirement for the K363 sprinkler may result in significant system cost savings through reduction of system pipe sizes.

For a given commodity hazard class and a given sprinkler response characteristic (RTI and temperature rating), the fire performance of sprinklers depend on storage height, ceiling clearance, ignition location relative to sprinklers, sprinkler discharge rate, discharge pressure, spray pattern and the volume median diameter of the spray drop-size distribution. For a fire directly underneath a sprinkler with a large ceiling clearance, the effect of drop size on ADD is expected to be quite important. As a fire is centered between two sprinklers with low ceiling clearance, water drops travel side way into the fire plume and the ADD would depend more on the spray pattern, discharge pressure and discharge rate than on drop size.

Chan and Kung [6] show that the penetration ratios of K80 standard sprinklers increase with spray volume median diameter. We expect that similar trends hold for the K202 and K363 sprinklers. It has been shown that the volume median diameter of the drop size distribution generated by geometrically similar sprinklers varies as the $-1 / 3$ power of the discharge pressure and $2 / 3$ power of the orifice diameter $[13,14]$. Under the assumption that the ESFR K202 and the K363 sprinklers are somewhat similar geometrically, the volume median diameter of the spray of the K363 sprinkler would be $64 \%$ greater than that of the K202 ESFR sprinkler for the discharge pressures employed. The penetration ability of the K363 sprinkler would be enhanced. With proper design of the sprinkler deflector to generate the desirable spray pattern, sufficient 
ADD can be provided by the K363 sprinkler to achieve fire suppression: even the response of the K363 sprinkler is delayed somewhat due to the use of a standard response link.

For the $12.2 \mathrm{~m}$ ceiling height, the K363 sprinkler at a discharge pressure of $0.21 \mathrm{MPa}$ and a sprinkler discharge rate of $522 \mathrm{~L} / \mathrm{min}$ achieved fire suppression for both the two fire scenarios.

For the $9.1 \mathrm{~m}$ ceiling height, the K363 sprinkler at a discharge pressure of $0.07 \mathrm{MPa}$ with a discharge rate of $302 \mathrm{~L} / \mathrm{min}$ or at a discharge pressure of $0.10 \mathrm{MPa}$ with a discharge rate of $369 \mathrm{~L} / \mathrm{min}$ provided fire suppression performance for the scenario with ignition between two sprinklers at a low storage top to ceiling clearance. For the scenario with ignition under a sprinkler at a large storage top to ceiling clearance, the sprinkler at a discharge pressure of $0.07 \mathrm{MPa}$ with a discharge rate of $302 \mathrm{~L} / \mathrm{min}$ only achieved fire control.

The ADD data confirms that as the ADD is greater than the required delivered density (RDD) for fire suppression, suppression of the fire can be expected. The results of the five fire tests show that a standardresponse K363 sprinkler can be as effective as ESFR sprinklers in providing protection for storages in warehouses with ceiling height up to $12.2 \mathrm{~m}$.

\section{REFERENCES}

[1] Yao, C., 1997. Overview of Sprinkler Technology Research. Fire Safety Science 5: 93-110. http://dx.doi.org/10.3801/IAFSS.FSS.5-93

[2] Heskestad, G. and Smith, H.F., "Plunge Test for Determination of Sprinkler Sensitivity," Technical Report, FMRC J. I. 3A1E2.RR, Factory Mutual Research Corporation, Norwood, MA, 1980.

[3] You, H.Z. and Kung, H.C., "Strong Buoyant Plumes of Growing Rack Storage Fires," Twentieth Symposium (International) on Combustion, The Combustion Institute, 1985, pp. 1547-1554. http://dx.doi.org/10.1016/S0082-0784(85)80649-4

[4] Kung, H.C., You, H.Z. and Spaulding, R.D., "Ceiling Flows of Growing Rack Storage Fires," Twenty-first Symposium (International) on Combustion, The Combustion Institute, 1988, pp. 121128. http://dx.doi.org/10.1016/S0082-0784(88)80238-8

[5] Chan, T.S., Kung, H.C., Yu, H.Z. and Brown, W.R., 1994. Experimental Study of Actual Delivered Density for Rack-storage Fires. Fire Safety Science 4: 913-924. http://dx.doi.org/10.3801/IAFSS.FSS.4-913

[6] Chan, T.S. and Kung, H.C., 2003. Comparison of Actual Delivered Density and Fire Suppression Effectiveness of Standard and Conventional Sprinklers in Rack-storage Fires. Fire Safety Science 7: 445-456. http://dx.doi.org/10.3801/IAFSS.FSS.7-445

[7] Yu, H.Z., Lee, J.L., Kung, H.C., Yu, H.Z. and Brown, W.R., 1994. Suppression of Rack-storage Fires by Water. Fire Safety Science 4: 901-912. http://dx.doi.org/10.3801/IAFSS.FSS.4-901

[8] Kung, H.C., Yu, H.Z., Brown, W.R. and Vincent, B.G., 1989. Four-tier Array Rack Storage Fire Tests with Fast-response Prototype Sprinklers. Fire Safety Science 2: 633-642. http://dx.doi.org/10.3801/IAFSS.FSS.2-633

[9] Kung, H.C., Vincent, B.G., Chan, T.S., Yu, H.Z. and Stavrianidis, P., 1997. Early Suppression Fast Response (ESFR) Sprinkler Protection for 12m High Warehouses. Fire Safety Science 5: 877888. http://dx.doi.org/10.3801/IAFSS.FSS.5-877

[10] Vincent, B. G. and Kung, H. C., "ESFR Sprinkler Large-scale Fire Tests - $35 \mathrm{ft}$ High Standard Plastic Commodity Rack Storage Arrays under a $40 \mathrm{ft}$ High Ceiling with Ignition Centered Below Two Sprinklers," Technical Report 0R1E4.RA(1), Factory Mutual Research Corporation, Norwood, MA, 1991.

[11] Stavrianidis, P. and Kung, H.C., "Fire Tests Using ESFR Sprinklers under a $40 \mathrm{ft}$ High Ceiling with Ignition under a Sprinkler," Technical Report 0R1E4.RA, Factory Mutual Research Corporation, Norwood, MA, 1990. 
[12] Chicarello, P.J., Troup, J.M.A., and Dean, R.K., "Large-scale Fire Test Evaluation of Early Suppression Fast Response (ESFR) Automatic Sprinklers," Technical Report OM2R5.RR/0M0J7.RR, Factory Mutual Research Corporation, Norwood, MA, 1985.

[13] Dombrowski, N., and Wolfsohn, D.L., "The Atomization of Water by Swirl Spray Pressure Nozzles,” Trans. Instn. Chem. Engrs, Vol. 50, 1972, p.259.

[14] Dundas, P.H., "The Scaling of Sprinkler Discharge: Prediction of Drop Size," Progress Report No. 10 in "Optimization of Sprinkler Fire Protection," Technical Report RC73-T-40, Factory Mutual Research Corporation, Norwood, MA, 1972. 